\title{
INKUIRI TERBIMBING DENGAN PENDEKATAN SAINTIFIK (SCIENTIFIC APPROACH) UNTUK MENINGKATKAN BERPIKIR KRITIS
}

\author{
Sudi Dul Aji*, Agustinus Bernadino, Muhammad Nur Hudha \\ Program Studi Pendidikan Fisika, Universitas Kanjuruhan Malang, Indonesia
}

\begin{abstract}
The purpose of this study is to describe the quality of learning Inkuiri model Guided by Scientific Approach (scientific approach) and know the improvement of critical thinking skills of SMK students on the topic Fluid Static. This research uses qualitative approach and the type of research used is Classroom Action Research (PTK), carried out through a process of gradual assessment consisting of 4 stages of planning, implementation, observation, and reflection. Based on the analysis of Learning Outcomes in the first cycle is $73.45 \%$ and on the second cycle $81.77 \%$. The students' critical thinking ability in the first cycle of the average of 71.67 students who meet the KKM is 17 students or $56.66 \%$ and on the second cycle 80.16 that meet the KKM is 23 students or $76.66 \%$. Based on this research can be concluded that Inkuiri model Guided by Scientific Approach (Scientific Approach) can increase critical thinking of student
\end{abstract}

Keywords: Fluid; Guided Inquiry; Scientific approach

\section{Abstrak}

Tujuan penelitian ini yaitu mendeskripsikan kualitas pembelajaran model Inkuiri Terbimbing dengan Pendekatan Saintifik (scientific approach) dan mengetahui peningkatan kemampuan berpikir kritis siswa SMK pada topik Fluida Statis. Penelitian ini menggunakan pendekatan kualitatif dan jenis penelitian yang digunakan adalah Penelitian Tindakan Kelas (PTK), dilaksanakan melalui proses pengkajian bertahap yang terdiri dari 4 tahap yaitu perencanaan, pelaksanaan, observasi, dan refleksi. Berdasarkan analis is hasil Keterlaksanaan Pembelajaran pada siklus I adalah 73,45\% dan pada siklus II 81,77\%. Kemampuan berpikir kritis siswa pada siklus I rata-rata siswa 71,67 yang memenuhi KKM adalah 17 siswa atau 56,66\% dan pada siklus II 80,16 yang memenuhi KKM adalah 23 siswa atau 76,66\%. Berdasarkan penelitian ini dapat disimpulkan bahwa model Inkuiri Terbimbing dengan Pendekatan Saintifik (Scientific Approach) dapat meningkatkan berpikir kritis siswa.

Kata Kunci: Fluida; Inkuiri Terbimbing; Pendekatan Saintifik

DOI : http://dx.doi.org/10.21067/mpej.v1i2.2148

Diterima: Agustus 2017; Disetujui: September 2017

\section{PENDAHULUAN}

Pembelajaran fisika dapat membentuk sikap ilmiah seperti ingin tahu, berpikir terbuka, berpikir kritis, keingginan memecahkan

\footnotetext{
* Corresponding Author: sudi@unikama.ac.id
}

masalah, membanggun sikap peka terhadap lingkungan dan bisa merespon suatu tindakan (Aji \& Hudha, 2015; 2016; Aji dkk, 2016; 2017). Pembelajaran fisika di sekolah pada hakikatnya memiliki 
tiga komponen yaitu sikap ilmiah, proses ilmiah dan produk ilmiah. Oleh karena itu, pembelajaran fisika di sekolah-sekolah tidak hanya fokus untuk meningkatkan penguasaan siswa terhadap fakta, konsep dan teori-teori sains, tetapi siswa dituntut untuk lebih mengerti dan memahami proses bagai mana fakta, konsep dan teori-teori tersebut ditemukan (Warpala, 2006).

Proses berpikir merupakan proses yang dilakukan oleh seseorang ketika menghadapi suatu permasalahan. Proses berpikir yang dilakukan dimulai dengan pemahaman terhadap masalah yang dihadapi.

Berpikir kritis merupakan suatu proses berpikir yang sistematis memungkinkan siswa dapat merumuskan dan mengevaluasi pendapat mereka. Berpikir kritis termasuk sebuah proses yang memungkinkan siswa mengevaluasi bukti, asumsi, logika dan bahasa yang mendasari pernyataan orang lain. Berpikir kritis adalah implementasi dan evaluasi yang terampil dan aktif terhadap observasi dan komunikasi, informasi dan argumentasi (Fisher, 2009; Hudha, 2012).

Berdasarkan hasil observasi dan wawancara dengan guru fisika SMK Budi Mulia Pakisaji, aspek untuk meningkatkan berpikir kritis dan pemahaman konsep fisika siswa masih belum terlihat. Hal ini dilihat dari prestasi belajar siswa kelas $\mathrm{X}$ TKJ 1 pada saat ujian tengah semester (UTS) dan nilai ulangan harian yang masih rendah karna belum mencapai KKM, hanya ada 10 siswa yang sudah mencapai KKM yaitu 33,33 \%, 20 siswa yang belum mencapai KKM yaitu 66,67 \% dan rata-rata nilainya 70 (KKM SMK Budi Mulia Pakisaji 75).

Salah satu upaya dalam meningkatkan pemahaman konsep dan berpikir kritis adalah melalui penerapan model pembelajaran yang berpusat pada siswa. Penerapan model pembelajaran yang berpusat pada siswa diyakini lebih baik meningkatkan berpikir kritis. Model inkuiri terbimbing akan mengubah cara belajar siswa yang selama ini lebih banyak bersifat menunggu informasi dari guru ke pembelajaran yang bersifat lebih bermakna. Pembelajaran inkuiri juga mempunyai tujuan untuk mengembangkan kemampuan intelektual siswa, sehingga dalam pembelajaran inkuiri siswa tidak hanya dituntut agar menguasai pelajaran akan tetapi dapat menggunakan potensi yang dimiliknya (Sanjaya, 2008).

Model inkuiri terbimbing tidak terlepas dari kegiatan ilmiah, karena model ini berlandasan pada penemuan yang ditempuh melalui serangkaian kegiatan ilmiah. Kegiatan ilmiah inilah yang disebut sebagai pendekatan saintifik (Yuliani dkk, 2017). Menurut McCollum (Gultom 2013) dijelaskan bahwa komponen-komponen penting dalam mengajar menggunakan pendekatan saintifik (scientific approach) diantaranya adalah guru harus 
menyajikan pembelajaran yang dapat meningkatkan rasa keingintahuan (foster a sense of wonder), meningkatkan keterampilan mengamati (encourage observation), melakukan analisis (push for analysis) dan berkomunikasi (require communication).

Penelitian ini menggunakan topik fluida statis. Di dalam topik fluida statis siswa secara berkelompok mampu mengkonstruksi pengalamannya sendiri dipercobaan atau pengamatan dari kehidupan sehari-hari sehingga siswa terlatih untuk mengembangkan kemampuan berpikir kritis. (Kartikasari, 2014).

Tujuan penelitian ini adalah untuk mendiskripsikan kualitas pembelajaran model inkuiri terbimbing dengan pendekatan saintifik (scientific approach), mengetahui apakah penerapan model inkuiri terbimbing dengan pendekatan saintifik (scientific approach) dapat meningkatkan berpikir kritis belajar fisika siswa SMK pada topik fluida statis, serta mengetahui apakah penerapan model inkuiri terbimbing dengan pendekatan saintifik (scientific approach) dapat meningkatkan pemahaman konsep belajar fisika siswa SMK pada topik fluida statis.

\section{METODE PENELITIAN}

Penelitian menggunakan pendekatan kualitatif untuk menghasilkan data deskriptif. Jenis penelitian yang digunakan dalam penelitian ini adalah Penelitian
Tindakan Kelas (PTK) (Arikunto, 2009). Penelitian ini melibatkan peneliti sebagai pengajar. Sesuai dengan pendekatan dan rancangan penelitian maka kehadiran peneliti mutlak diperlukan. Hal ini disebabkan karena peneliti yang merencanakan, melaksanakan, mengumpulkan data, menganalisis dan melaporkan hasil penelitian. Untuk mengumpulkan data yang diperlukan, peneliti di bantu oleh guru fisika atau teman sejawat.

Penelitian ini dilaksanakan di SMK Budi Mulia Pakisaji. Pemilihan lokasi ini berdasarkan pertimbangan saat ditemukan permasalahan yang akan diteliti, juga belum pernah diterapkan model inkuiri terbimbing dengan pendekatan saintifik (scientific approach).

Subjek penelitian adalah siswa kelas X TKJ-1 yang berjumlah 30 siswa di SMK Budi Mulia Pakisaji tahun pelajaran 2016-2017 dengan pertimbangan bahwa siswa pada sekolah yang akan dijadikan subjek penelitian memiliki kemampuan yang heterogen. Pemilihan dan penentuan subjek penelitian berdasarkan pada tujuan, yaitu untuk mengetahui kualitas pembelajaran, peningkatan berpikir kritis dan pemahaman konsep belajar fisika.

\section{HASIL DAN PEMBAHASAN}

1. Keterlaksanaan Pembelajaran Data tentang keterlaksanaan pembelajaran diperoleh melalui observasi terhadap pelaksanaan pembelajaran dengan menggunkan pedoman penilaian pelaksanaan 
pembelajaran. Data hasil penelitian keterlaksanaan pembelajaran diperoleh melalui lembaran observasi yang dibantu dan diamati oleh dua orang pengamat. Data mentah ini kemudian diolah dan dianalisis melalui tiga tahap yaitu reduksi, penyajian data dan pengambilan kesimpulan. Penyimpulan data ini diambil dari pemberian dan pengolahan skor hasil penelitian.

Pada proses pembelajaran yang dilaksanakan pada kegiatan pembelajaran yang dihasilkan dari data observasi menggunakan pedoman keterlaksanaan pembelajaran yang terdiri dari beberapa kegiatan pendahuluan, kegiatan inti dan kegiatan penutup, yang diamati secara terus menerus selama mengadakan penelitian dalam dua siklus.

Pada siklus I kegiatan pendahuluan lebih rendah dari siklus II hal ini dikarenakan dalam memberikan acuan, suara guru kurang keras sehingga siswa tidak mengerti langkah apa yang harus dilakukan, akibatnya siswa tidak mengerti tentang materi pembelajaran. Sedangkan pada siklus II kegiatan pendahuluan meningkat hal ini dikarenakan suara guru sudah lantang sehingga siswa lebih mudah memahami materi yang disampaikan oleh guru. Rata-rata persentase yang diperoleh dalam keterlaksanaan pembelajaran siklus I sebesar 72,91 $\%$ sedangkan rata-rata persentasi yang diperoleh dalam keterlaksanaan pembelajaran pada siklus II sebesar $78,12 \%$. Sehingga dapat disimpulkan terdapat peningkatan persentasi pada tahap pendahuluan.

Kegiatan inti sesuai dengan langkah-langkah model inkuiri terbimbing yaitu merumuskan masalah, merumuskan hipotesis, mengumpulkan data, menguji hipotesis, dan merumuskn kesimpulan.

a. Merumuskan masalah

Pada tahap ini persentasi siklus

I sebesar 69,44\% dengan kriteria cukup sedangkan pada siklus II persentase $77,78 \%$ dengan kriteria baik. Pada tahap merumuskan masalah sangat jelas persentse keterlaksanaan model pembelajaran inkuiri terbimbing meningkat disebabkan pada tahap ini guru guru menumbuhkan rasa ingin tahu pada siswa dengan memberikan kasus dalam kehidupn sehari-hari.

b. Merumuskan Hipotesis peningkatan persentasi hal ini dapat dilihat dari persentasi siklus I sebesar $71,76 \%$ meningkat pada siklus II menjadi $81,87 \%$. Hal ini terjdi karena siswa diberikan kasus dalam kehidupan sehari-hari.

c. Mengumpulkan Data

Persentasi keterlaksanaan

pembelajaran pada tahap pengumpulan data pada siklus I sebesar 79,16\% meningkat pada siklus II menjadi $81,25 \%$ dengan kriteria baik. Hal ini terjadi karena siswa sudah mulai terbisa dalam suasana pengumpulan data dengan cara melakukan demonstrasi.

d. Menguji Hipotesis 
Pada tahap menguji hipotesis siswa berpedoman pada LKS, dan menjawab soal pada LKS, selain itu bila ada kelompok yang mengalami kesulitan, guru memberikan bimbingan hal ini berbanding lurus dengan persentase keterlaksanan pada siklus II sebesar $80,55 \%$ dengan kriteria baik, pada siklus I persentase keterlaksanaan pembelajaran sebesar $75 \%$.

\section{e. Merumuskan kesimpulan \\ Pada tahap ini persentase} keterlaksanaan pada siklus I sebesar $72,71 \%$ meningkat pada siklus II menjadi $86,11 \%$. Hal itu terjadi karna pada siklus II masing-masing kelompok mempersentasikan dan kelompok yamg lain menangapi.

Rata-rata persentasi yang diperoleh dalam keterlaksanaan pembelajaran siklus I sebesar 73,49 $\%$ sedangkan rata-rata persentasi yang diperoleh dalam keterlaksanaan pembelajaran pada siklus II sebesar $81,46 \%$. Pada siklus I lebih rendah dari siklus II hal ini dikarenakan pada tahap merumuskan masalah sebagian siswa tidak memperhatiakan apa yang disampaikan oleh guru sehingga siswa kebingungan menentukan rumusan masalah. Sedangkan pada siklus II meningkat hal ini dikarenakan siswa sudah memperhatikan apa yang disampaikan oleh guru. Sehingga dapat disimpulkan terdapat peningkatan persentasi pada tahap inti.

Kegiatan penutup pada tahap menutup pembelajaran, rata-rata persentasi yang diperoleh dalam keterlaksanaan pembelajaran siklus I pada tahap ini sebesar 73,80 \% sedangkan rata-rata persentasi yang diperoleh dalam keterlaksanaan pembelajaran pada siklus II sebesar $86,90 \%$. Pada siklus I lebih rendah karena guru tidak membuat kesimpulan di akhir pembelajaran. Sedangkan pada siklus II guru sudah membuat kesimpulan di akhir pembelajaran. Sehingga dapat disimpulkan tahap menutup pembelajaran terdapat peningkatan persentasi.

Pada pembelajaran siklus I keterlaksanaan pembelajaran sudah terlaksana dengan cukup baik. Terlihat dari rata-rata keterlaksanaan pembelajaran siklus I 73,45 \% dan berada pada kerteria cukup baik. Pada pembelajaran siklus II adanya peningkatan pencapaian keberhasilan yaitu $81,77 \%$ dan berada pada kriteria baik. Peningkatan ini dikarenakan guru sudah mulai terbiasa menerapkan model pembelajaran inkuiri terbimbing dengan pendekatan saintifik di dalam kelas, sehingga apa saja yang akan disampaikan dan dilakukan sudah bisa dihafal oleh guru.

Berdasarkan uraian di atas model pembelajaran inkuiri terbimbing dengan pendekatan saintifik dalam pelaksanaannya terdapat peningkatan proses pembelajaran dari siklus I dan siklus II. Yakni pada siklus I sebesar 73,45 $\%$ dan pada siklus II sebesar 81,77 $\%$.

\section{Berpikir Kritis}

Penelitian ini mengukur peningkatan berpikir kritis siswa pada mata pelajaran fisika. Indikator 
\begin{tabular}{lllr} 
berpikir kritis & ini mengunakan \\
inikator Ennis & (Fisher, 2009). \\
Indikator yang & digunakan & dalam \\
penelitian ini ada & 3, yaitu yaitu (1) \\
membuat & \multicolumn{2}{c}{ induksi } & dan \\
mempertimbangkan induksi; & (2)
\end{tabular}

Bertanya dan menjawab pertanyaan tentang sesuatu penjelasan dan tantangan; (3) mendefinisikan istilah.

Adapun pengertian dari masing-masing sub indikator yang digunakan dalam penelitian ini adalah sebagai berikut.

Bertanya dan menjawab
pertanyaan
Indikator yang digunakan dalam aspek ini adalah bertanya dan menjawab pertanyaan, pada indikator tersebut terdapat sub indikator yaitu menanya dan menjawab pertnyaan yang meliputi, apa, mengapa dan menyebutkan contohnya. Rata-rata persentse yang diperoleh pada siklus I sebesar 66,95\% sedangkan pada siklus II sebesar $74,71 \%$ berarti ada peningkatan sebesar $7,76 \%$ dan aspek ini memenuhi kriteria cukup. Hal ini disebabkan, pada saat pembelajaran guru melatih bagaimana memberikan penjelasan terhadap suatu masalah sehingga pada saat tes dilaksanakan siswa sudah terbiasa berargumen dan memberikan penjelasan.

b. Membuat induksi dan mempertimbangkan induksi

Pada aspek ini sub indikator yang digunakan yaitu melakukan generalisasi dan membuat kesimpulan, rata-rata persentase yang diperoleh dariaspek ini adalah pada siklus I sebesar $76,7 \%$ dan pada siklus II diperoleh sebesar 86,8\%, berarti ada peningktan pada aspek ini sebesar $10,1 \%$ dan aspek ini memenuhi kriteria baik. Kenaikan tersebut dikarenakan pada tahap merumuskan kesimpulan, guru memberikan kesempatan kepada siswa untuk menanggapi hasil diskusi pada perwakilan kelompok yang sedang menjelaskan jwaban di depan kelas sehingga pada saat dilaksanakan tes siswa sudah mampu untuk membuat kesimpulan.

c. Mendefinisikan istilah Rata-rata persentase aspek ini pada siklus I sebesar $80 \%$ dan siklus II sebesar $90,8 \%$, berarti peningkatan pada siklus ini sebesar $10,8 \%$ dan aspek ini memenuhi kriteria sangat baik. Hal ini disebabkan guru selalu menjelaskan tentang suatu definisi yang masih belum mengerti siswa.

Dari hasil penelitian siklus I dan siklus II, rata-rata persentase kemampuan berpikir kritis siswa meningkat sebesar 5,61\%. Dimana siklus I diperoleh $74,55 \%$ dan pada siklus II yaitu $80,16 \%$. Inkuiri memerlukan identifikasi asumsi yang digunakan, pengunaan pemikiran logis dan kritis serta pertimbangan terhadap penjelasan mengenai suatu hal (Dow dkk, 2000). Kemampuan siswa dalam penelitian ini misalnya: bagaimana siswa melibatkan dalam pengamatan, pencarianan bukti atas suatu permasalahan dan menarik kesimpulan dari hasil pencarian bukti/fakta. Selain itu ada interaksi sosial seperti interaksi sesama teman dalam kelompok dalam melakukan diskusi untuk memecahkan 
permasalahan yang sedang dihadapi. Berpikir kritis fisika siswa yang mengunakan pembelajaran inkuiri terbimbing lebih baik dibandingkan dengan siswa yang melakukan pembelajaran konvensional (Sochibin dkk, 2009; Puspita \& Jatmiko, 2013).

3. Pemahaman Konsep Pemahaman konsep belajar siswa pada proses pembelajaran mengalami peningkatan pada siklus I dan II. Pada siklus I rata-rata pemahaman konsep belajar siswa sebesar 71,34 dan pada siklus II ratarata pemahaman konsep siswa sebesar 78,17. Sedangkan ditinjau dari ketuntasan setiap siswa yang memenuhi KKM 75 pada siklus I sebanyak 16 siswa yakni 53,34\% dan pada siklus II jumlah siswa yang tuntas sebanyak 24 siswa yakni sebesar $80 \%$. Faktor yang menyebabkan peningkatan tersebut dikarenakan pada siklus I karena kurang bisanya guru dalam mengontrol kelas. Sedangkan pada siklus II guru sudah bisa menjaga suasana kelas yang nyaman karena siswa sudah bisa dikontrol sehingga nilai pemahaman konsep siswa pada siklus II meningkat. Selain itu penerapan pembelajaran inkuiri terbimbing dengan pendekatan saintifik (scientific approach) lebih mempermudah siswa dalam memhami konsep-konsep fisika yang sedang dipelajari.

\section{SIMPULAN}

Simpulan yang dapat diambil dari penelitian ini adalah kualitas keterlaksanaan pembelajaran dengan menggunakan model inkuiri terbimbing dengan pendekatan saintifik (scientific approach) dikategorikan baik dan dapat meningkatkan berpikir kritis siswa serta dapat meningkatkan pemahaman konsep belajar siswa. Implikasi dari penelitian ini adalah pemanfaatan model dari inkuiri terbimbing dengan pendekatan saintifik (scientific approach) yang dapat diterapkan dalam proses pembelajaran di sekolah.

\section{DAFTAR PUSTAKA}

Aji, S. D., \& Hudha, M. N. 2015. Dampak PBL Terhadap Kerja Ilmiah Mahasiswa pada Perkuliahan Pengembangan Media Pembelajaran. Jurnal Inspirasi Pendidikan, 6(1), 708-714.

Aji, S. D., \& Hudha, M. N. 2016. Kerja Ilmiah Siswa SMP dan SMA melalui Authentic Problem Based Learning (APBL). Jurnal Inspirasi Pendidikan, 6(1), 835-841.

Aji, S. D., Hudha, M. N., \& Permatasari, A. 2016. Authentic Problem Based Learning (APBL) untuk Meningkatkan Kemampuan Pemecahan Masalah Fisika Siswa. Prosiding SNPS (Seminar Nasional Pendidikan Sains), 3, 299302.

Aji, S. D, Hudha, M. N \& Rismawati, A. Y. 2017. Pengembangan Modul Pembelajaran Fisika Berbasis Problem Based Learning untuk 
Meningkatkan Kemampuan Pemecahan Masalah Fisika. Science Education Journal, 1(1), 36-51.

Arikunto, S. 2009. Penelitian Tindakan Kelas. Jakarta: PT Bumi Aksara.

Dow. P. 2000. Inkuiri Dan StandarStandar Pendidikan Sains Nasional. Terj. Ismunandar, dkk. Wasington, D.C.: National Academies Press.

Fisher, A 2009. Berpikir Kritis: Sebuah Pengantar. Jakarta: Erlangga

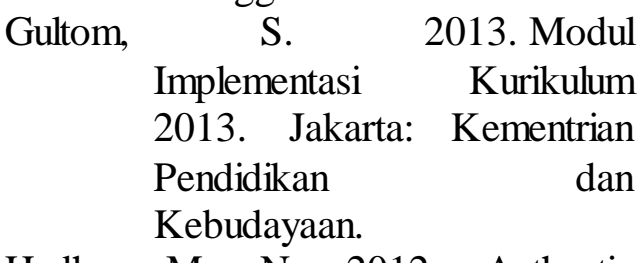

Hudha, M. N. 2012. Authentic learning untuk meningkatkan kemampuan berpikir kritis mahasiswa program studi pendidikan fisika Universitas Negeri Malang dalam mata kuliah strategi pembelajaran fisika. Authentic learning untuk meningkatkan kemampuan berpikir kritis mahasiswa program studi pendidikan fisika Universitas Negeri Malang dalam mata kuliah strategi pembelajaran fisika/Muhammad Nur Hudha.

Kartikasari. I. 2014. Penerapan Model Pembelajaran message Berkonten Proses Keterampilan Sains Dengan Coverative LearningType Group Investigation Terhadap Kemampuan Berpikir Kritis Siswa SMA. Skripsi (tidak diterbitkan). Yogyakarta: UIN Sunan Kalijaga.
Puspita, A. T., \& Jatmiko, B. 2013. Implementasi Model Pembelajaran Inkuiri Terbimbing (Guided Inquiry) terhadap Keterampilan Berpikir Kritis Siswa pada Pembelajaran Fisika Materi Fluida Statis Kelas XI di SMA Negeri 2 Sidoarjo. Inovasi Pendidikan Fisika, 2(3).

Sanjaya, W. 2008. Kurikulum dan Pembelajaran: teori dan praktik pengembangan KTSP. Jakarta: Kencana Prenada Media Group.

Sochibin, A., Dwijananti, P., \& Marwoto, $\quad$ P. 2009. Penerapan model pembelajaran inkuiri terpimpin untuk peningkatan pemahaman dan keterampilan berpikir kritis siswa SD. Jurnal Pendidikan Fisika Indonesia, 5(2).

Warpala, I. W. S. 2006. Pengaruh pendekatan pembelajaran dan strategi belajar kooperatif yang berbeda terhadap pemahaman dan keterampilan berpikir kritis dalam pembelajaran IPA SD. Disertai tidak diterbitkan. Malang: Universitas Negeri Malang.

Yuliani, H., Mariati., Yulianti, R., \& Herianto, C. 2017 Keterampilan Berpikir Kreatif Pada Siswa Sekolah Menengah Di Palangka Raya Menggunakan Pendekatan Saintifik. Jurnal Pendidikan Fisika dan Keilmuan (JPFK). 3 (1), 4856. 